\title{
Managing enterprises and ERP systems: a contingency model for the enterprization of operations
}

\section{INTRODUCTION}

Enterprise Resource Planning (ERP) systems for manufacturing organisations have developed extensively over recent decades in response to changing business requirements, technological developments, and new organizational strategies (Palaniswamy and Frank, 2000). However, studies on ERP systems development tend to focus on ERP functional improvements (He, 2004; Michel, 2000; Chen, 2001) rather than on how ERP systems fit with operations spanning inter-organisational boundaries to implement collaborative strategies. Therefore this research attempts to explain how different types of ERP systems fit to different types of enterprises to create sustainable competitive advantage.

This research uses the European Commission's definition of an enterprise which is, “... an entity including partnerships or associations that can be made up of parts of different companies" (European Commission, 2003). Building on this definition this research does not consider manufacturing operations to be single legal entities operating in isolation, but instead embodies enterprise management concepts (Karlsson, 2003), where parts of companies work with parts of other companies to deliver complex product and service systems. Some operations management researchers are already recognizing the importance of enterprise management concepts and realise that enterprises can no longer be described through simple contractual exchanges; but are better thought of as operational interdependencies based on complex interactivities of information technology (IT) combined with newly emerging concepts about the management of enterprises (Banker et al., 2010; Gallivan and Depledge, 2003; MacBeth, 2002). Likewise, information systems (IS) researchers realise that integrated technical solutions, which may make the enterprise management concept a full technical reality, are not so very far away (Chorafas, 2001, p.13; Porter and Millar, 1985; Rayport and Sviokla, 1995). 
However, despite an emerging body of literature about inter-firm forms (i.e. the enterprise) (Binder and Clegg, 2006; De Toni and Tonchia, 2003; Zhang and Dhaliwal, 2008) and inter-organisational information systems (Rodon et al., 2011) the relationship between the management of enterprises (parts of different companies working together) and ERP systems types remains theoretically under-developed. Thus we seek to address this gap through some new empirical data and the extension of two a priori conceptual frameworks. The specific objectives of this paper are to (i) summarise recent trends in ERP systems development (ii) summarise recent trends in enterprise management (iii) develop a conceptual contingency framework to explain correlations between ERP system types and enterprise structure types and (iv) illustrate them using a longitudinal case study from a manufacturing company.

\section{LITERARY CONTEXT}

\section{From ERP to ERPII and on towards ERPIII}

Traditional ERP systems are internally integrated information systems (IS) which are used to gain operational and strategic competitive advantage (Blackstone and Cox, 2005, p.38; He, 2004) by primarily supporting core internal functions such as operations and production, and which may be extended to include other closely related functions such as sales and distribution, and accounting and finance (Al-Mudimigh et al., 2001; Davenport, 1998). These traditional ERP system types (sometimes also referred to as ERPI) typically have a high degree of proprietary in-house development requiring considerable financial commitment to implement and integrate with other organisational applications; such as Product Data Management (PDM) and Decision Support Systems (DSS) (Stevens, 2003; Themistocleous et al., 2001).

The origins of ERP systems are firmly based in manufacturing and traditionally do not necessarily support the increasing scope of future business requirements for Internet based commerce particularly well (Bond et al., 2000; Moller, 2005; Songini, 2002; Vazquez-Bustelo and Avella, 2006). Therefore, further functional modules are often developed as 'add-ons' to form ERPII type 
systems and the mantra of "ERP is dead - long live ERPII" is often used by contemporary systems developers (Eckartz et al., 2009). Thus traditional ERP systems are slowly being usurped by ERPII (sometimes also known as 'XRP' - eXtended Resource Planning) as ERPII systems are recognized as being more integral to advanced business strategy - primarily by facilitating inter-organizational collaborations of operations to close and trusted partners (Bagchi et al. 2003). Modules such as Advanced Planning and Scheduling (APS), Supply Chain Management (SCM), Customer Relationship Management (CRM), Demand Chain Management (DCM), Vendor Management Inventory (VMI), Business Intelligence (BI), and Data Warehousing (DW) are key parts of ERPII systems - which give greater potential for inter-organizational operations (Davenport and Brooks, 2004). One might say that the first generation of ERP primarily supported and enhanced single organizational operations (Akkermans et al., 2003) whilst ERPII supports “... resource planning co-operations between different organizations at a meta-level" (Daniel and White, 2005).

Currently ERPII is the dominant type of system to support modern manufacturing enterprises. However as competition increases and markets become even more turbulent, many manufacturers are trying to re-design their operations and ERP systems to have even greater agility (Banker et al., 2010; Cao \& Dowlatshahi, 2005). As a result information systems solutions based on technologies such as EAI (Enterprise Application Integration), SOA (Service Orientated Architectures), SaaS (Software as a Service) (Bass and Mabry, 2004), utility computing (Maurizio et al., 2007; Rappa, 2004) and open-sources (Benlian and Hess, 2011) are becoming increasingly prevalent. These technologies bring with them further flexibility, agility, efficiency, scalability and re-configurability to ERP systems and the operations they support - mainly because they enhance the potential for inter-organisational connectivity (Torbacki, 2008; Wilkes and Veryard, 2004).

The future for ERP systems is still uncertain though - as SOA, SaaS, Utility and openly-sourced enterprise applications bring new challenges concerning granularity of data-sharing, business privacy and de-centralisation of strategic objectives (Candido et al., 2009; Xu et al., 2002). Despite these new challenges one can observe these emerging technologies changing the way that ERP systems are currently being perceived and developed. For instance one can find "Virtual Enterprise Resource Planning (VERP)" and "Federated ERP" concepts being deployed using cloud 
computing, SOA, SaaS and PaaS (Platform as a Service) technologies (Cummins, 2009; Pal and Pantaleo, 2005). Such technical and conceptual IS developments should allow more sustainable competitive advantage and make the enterprise management concept a reality in the near future; thus for managers who may be seeking to temporise their structure and operations strategy in preparation for economic turbulence and uncertainty it's an important trend to be aware of.

In this paper we refer to the next generation of enterprise resource planning systems as 'ERPIII'. The authors define ERPIII as a flexible information system incorporating web-based technology which enables enterprises to offer increasing degrees of connectivity, collaboration and dynamism through increased functional scope and scalability. Wood (2010) describes ERPIII from a practitioner-based definition, “...through collaboration, direct contact, social media, and various data streams, within and outside of the enterprise, ERPIII integrates marketplace fans and critics into the extending ERP and ERPII organizations. From the integration of customers and vendors beyond the enterprise boundaries a constructive dialog or information exchange is created to innovate, produce, and then sell (or distribute) better products or services". Woods' definition is comparable to the authors', but falls short of considering the latest contemporary management thinking about managing enterprise cited in this paper.

Table 1 summarizes the recent ERP development trends outlined above; from ERP to ERPII, and on towards ERPIII (objective i) on which the new contingency framework (objective iii) described towards the end of this paper is partly founded. Table 1 does this by citing key works in 5 key elements of ERP: role of system, business scope, functions addressed, processes supported, and information systems architecture (see Table 1). 
Table 1. Summary of ERP trends: ERP to ERPII, and on towards ERPIII

\begin{tabular}{|c|c|c|c|}
\hline Key Element & ERP & ERPII & ERPIII \\
\hline Role of system & $\begin{array}{l}\text { Single organization } \\
\text { optimization and } \\
\text { integration (Park and } \\
\text { Kusiak, 2005; Scott } \\
\text { and Vessey, 2000; } \\
\text { Akkermans et al., } \\
\text { 2003) }\end{array}$ & $\begin{array}{l}\text { Multi-organisation } \\
\text { participation with some } \\
\text { collaborative commerce } \\
\text { potential (Zrimsek, 2003; } \\
\text { Bagchi et al., 2003; Daniel and } \\
\text { White, 2005) }\end{array}$ & $\begin{array}{l}\text { Multi-organisation, Internet } \\
\text { based, with full collaborative } \\
\text { commerce functionality } \\
\text { (Hauser } \text { et al., 2010; Ponis } \\
\text { and Spanos, 2009; Torbacki, } \\
\text { 2008) }\end{array}$ \\
\hline Business scope & $\begin{array}{l}\text { Manufacturing and } \\
\text { distribution focus, } \\
\text { automatic business } \\
\text { transactions (Chen, } \\
\text { 2001; Al-Mudimigh et } \\
\text { al., 2001) }\end{array}$ & $\begin{array}{l}\text { Often sector-wide offering } \\
\text { upstream and downstream } \\
\text { integration (Bendoly et al., } \\
\text { 2004; Bond et al., 2000) }\end{array}$ & $\begin{array}{l}\text { Facilitating cross sectors } \\
\text { strategic alliances } \\
\text { (Muscatello et al., 2003; } \\
\text { Wood, 2010; Wilkes and } \\
\text { Veryard, 2004) }\end{array}$ \\
\hline Functions addressed & $\begin{array}{l}\text { Manufacturing, product } \\
\text { data, sales and } \\
\text { distribution, finance } \\
\text { (Davenport, 1998; } \\
\text { Monk and Wagner, } \\
\text { 2009) }\end{array}$ & $\begin{array}{l}\text { Most internal organisational } \\
\text { functions supported with } \\
\text { some limited supplier and } \\
\text { customer integration } \\
\text { (Weston, 2002; Li, 1999; } \\
\text { Weston Jr., 2003) }\end{array}$ & $\begin{array}{l}\text { All internal functions supported } \\
\text { plus core inter-company } \\
\text { processes (Wood, 2010; } \\
\text { Hauser et al., 2010) }\end{array}$ \\
\hline Processes supported & $\begin{array}{l}\text { Internal, hidden, with an } \\
\text { intra-company } \\
\text { boundary (Al-Mashari } \\
\text { et al., 2003; Markus } \\
\text { and Tanis, 2000) }\end{array}$ & $\begin{array}{l}\text { Externally connected with } \\
\text { intra-enterprise (i.e. } \\
\text { intercompany) focus } \\
\text { (Moller, 2005; Songini, } \\
\text { 2002; Tapscott et al., 2000; } \\
\text { Bond et al., 2000) }\end{array}$ & $\begin{array}{l}\text { Externally connected, open } \\
\text { network to create borderless } \\
\text { inter-enterprise / } \\
\text { industry-wide focus (Wood, } \\
\text { 2010; Ponis and Spanos, } \\
\text { 2009; Muscatello et al., } \\
\text { 2003) }\end{array}$ \\
\hline \multirow[t]{2}{*}{ Information system } & $\begin{array}{l}\text { Web-aware } \\
\text { Closed and monolithic } \\
\text { (Hicks and Stecke, } \\
\text { 1995; Stevens, 2003; } \\
\text { Themistocleous et al., } \\
\text { 2001) }\end{array}$ & $\begin{array}{l}\text { Web-based, componentized, } \\
\text { non-proprietary (Monk and } \\
\text { Wagner, 2009; Callaway, } \\
\text { 2000) }\end{array}$ & $\begin{array}{l}\text { Web-based communication, } \\
\text { service-oriented architecture } \\
\text { (Hofmann, 2008; Ponis and } \\
\text { Spanos, 2009) }\end{array}$ \\
\hline & & $\begin{array}{l}\text { Internally and externally } \\
\text { available, often subscribed } \\
\text { to by joint ventures } \\
\text { (Ericson, 2001; Moller, } \\
\text { 2005; Li, 1999) }\end{array}$ & $\begin{array}{l}\text { External exchange via open } \\
\text { source and cloud computing } \\
\text { (De Maria et al., 2011; Buco } \\
\text { et al., 2004) }\end{array}$ \\
\hline
\end{tabular}




\section{Collaborative Enterprise Governance}

The Collaborative Enterprise Governance (CEG) concept can be used to help manage inter-organisational (e.g. intra-enterprise) strategy. This is important because it is widely accepted that embracing new business partnerships and collaborative arrangements can contribute to the sustainability of a business (Achrol and Kotler, 1999). For instance Tencati and Zsolnai (2009) state that the enterprise concept helps a business fit better within its [business] environment, social, and cultural contexts. Likewise Binder and Clegg (2006) claim that, “... the success of collaborative enterprise management [a.k.a. governance] depends on the ability of companies to intermediate their internal core competences into other participating companies' value streams and simultaneously outsource their own peripheral activities...". Similarly Li and Williams (1999) indicate that "firms should focus on their core competences and share expertise and risks with each other in order to develop inter-firm collaboration in strategic processes..." This thinking indicates that competitiveness relies on the overall performance of all partners in an enterprise rather than just one company's internal operations. This research focuses on the three main types of enterprises: the Vertically Integrated Enterprise (VIE), the Extended Enterprise (EE), and the Virtual Enterprise (VE) to illustrate enterprise management behaviour.

Vertically integrated enterprises (VIE) operate as large single well-integrated multi-functional firm striving for scales of economy, they typically have bureaucratic reporting hierarchies (Lynch, 2003) which evolve as, "a response to pre-existing market power problems or as a strategic move to create or enhance market power in upstream and downstream markets" (Joskow, 2003, p.25). A VIE will typically process raw materials through to end-consumer products and services to embed a firm within an industry (Vallespir and Kleinhans, 2001). A classic example is the Ford Motor Company is in its $20^{\text {th }}$ century heyday (Monteverde and Teece, 1982; Crandall, 1968). As a result competitiveness maybe gained through reduced transaction costs (Harrigan, 1985), stronger quality control, higher barriers to new entrants (Rothaermel et al., 2006) and rapid response to volume changes (Richardson, 1996). Some research suggests that 'make-or-buy' decisions (Vallespir and Kleinhans, 2001); strategic outsourcing and alliances make further enhancements to a VIE set-up (Arya and Mittendorf, 2008). Therefore, the downside to VIEs (Argyres, 1996) is that their 
structure and size can inhibit engagement with other organisations; hence the rate at which changing market requirements are addressable in collaboration with other organisations is reduced. To combat the downsides of VIEs - the extended enterprise strategy and structure should be used instead.

The 'extended enterprise' (EE) concept, in contrast to the VIE, is defined by Davis and Spekman (2004, p.20) as “... the entire set of collaborating companies...which bring value to the marketplace...” and by Lyman et al. (2009) as “... a business value network where multiple firms own and manage parts of an integrated enterprise". This allows practices such as just-in-time (JIT) supply chain logistics (Sutton, 2006), collaborative innovation (Owen et al., 2008), and data warehouse interoperability (Triantafillakis et al., 2004) to be more easily deployed across company boundaries. This is because an EE structure allows organisations to focus on their core business and technical activities whilst outsourcing non-core activities to other members in their extended enterprise (Thun, 2010). Thus extended enterprises are deemed to be more agile than vertically integrated enterprises. But despite reduced cross-company boundaries, even EEs cannot manage to follow very high economic turbulence and unpredictability because they operate in a partially restricted environment operated by known and trusted members only.

In further contrast to both VIEs and EEs highly turbulent and very unpredictable market behaviours are best coped with by virtual enterprises (VE) (Byrne and Brandt, 1993) as virtual enterprises (VEs) are the most agile type of enterprise. In this context VEs are best thought of as a jigsaw of operations and information systems from more than one business entity loosely governed by decentralised specific objectives which delivers value to its markets (Martinez et al., 2001). Virtual inter-organisational relationships like these can facilitate innovative agile manufacturing more easily (Cho et al., 1996; Sharp et al., 1999) and deal with dramatic dynamic market changes through Internet based information and communication technologies (ICTs) (Madu and Kuei, 2004). This is because firms' tendencies towards temporising strategy and structure are more easily addressed. 
Table 2 summarises the comparison between vertically integrated (VIE), extended (EE) and virtual enterprise (VE) types as discussed above (objective ii) using key elements which both characterises and differentiates them on structural, strategic operations and IS bases. The enterprise types in Table 2 (along with ERP types in Table 1) are used as partial bases for the new contingency framework (objective iii) given towards the end of this paper.

Table 2. Comparisons between VIE, EE, and VE (adapted from Binder and Clegg; 2007a and 2007b)

\begin{tabular}{|c|c|c|c|}
\hline Key Element & $\begin{array}{c}\text { Vertically Integrated } \\
\text { Enterprise (VIE) }\end{array}$ & $\begin{array}{l}\text { Extended Enterprise } \\
\text { (EE) }\end{array}$ & $\begin{array}{l}\text { Virtual Enterprise } \\
\text { (VE) }\end{array}$ \\
\hline $\begin{array}{l}\text { Characteristic } \\
\text { of core } \\
\text { competencies }\end{array}$ & $\begin{array}{l}\text { Mature and well accepted } \\
\text { Large scale of economies }\end{array}$ & $\begin{array}{l}\text { Semi-mature with pilot } \\
\text { experience } \\
\text { Ideal for production ramp-up } \\
\text { scenarios }\end{array}$ & $\begin{array}{l}\text { Quick respond to the } \\
\text { changing market and } \\
\text { environment } \\
\text { Low overheads }\end{array}$ \\
\hline Strategic aims & Long term objectives & Medium-long term objectives & Short-term objectives \\
\hline $\begin{array}{r}\text { Partnership } \\
\text { purposes }\end{array}$ & $\begin{array}{l}\text { Long-term indefinite } \\
\text { co-operation }\end{array}$ & $\begin{array}{l}\text { Medium-long-term } \\
\text { collaboration on variety of } \\
\text { projects and products }\end{array}$ & $\begin{array}{l}\text { Temporary team-working } \\
\text { for single project or } \\
\text { products }\end{array}$ \\
\hline $\begin{array}{l}\text { Organization } \\
\text { stability }\end{array}$ & $\begin{array}{l}\text { Stable hierarchy and inflexible } \\
\text { structure }\end{array}$ & $\begin{array}{l}\text { Relatively stable across the } \\
\text { product value chain }\end{array}$ & $\begin{array}{l}\text { Dynamic organization with } \\
\text { core competences }\end{array}$ \\
\hline $\begin{array}{l}\text { Organization } \\
\text { type }\end{array}$ & $\begin{array}{l}\text { Command \& control unity } \\
\text { Emphasis on scales of } \\
\text { economies }\end{array}$ & $\begin{array}{l}\text { Product/service value-chain } \\
\text { based }\end{array}$ & $\begin{array}{l}\text { Frequently project or niche } \\
\text { market based }\end{array}$ \\
\hline $\begin{array}{l}\text { Co-ordination } \\
\text { of partnership }\end{array}$ & $\begin{array}{l}\text { Original equipment } \\
\text { manufacturer supervises } \\
\text { relationship with the partners }\end{array}$ & $\begin{array}{l}\text { Manufacturer or prime } \\
\text { contractor supervises the } \\
\text { partnership }\end{array}$ & $\begin{array}{l}\text { The most strategically } \\
\text { influential member } \\
\text { 'orchestrates' } \\
\text { co-operation }\end{array}$ \\
\hline $\begin{array}{r}\text { Operational } \\
\text { challenges }\end{array}$ & $\begin{array}{l}\text { Legacy system transferring } \\
\text { approaches (e.g. big bang vs. } \\
\text { incremental ways) }\end{array}$ & $\begin{array}{l}\text { Synergistic among } \\
\text { complementing core } \\
\text { competencies } \\
\text { Compatibility around partners } \\
\text { and IS/IT }\end{array}$ & $\begin{array}{l}\text { Dynamic operating and } \\
\text { unpredictable business } \\
\text { environment } \\
\text { Psychological issues }\end{array}$ \\
\hline Risk degree & Comparative low & Moderate & Intensely high \\
\hline $\begin{array}{l}\text { IS/IT } \\
\text { facilitators }\end{array}$ & $\begin{array}{l}\text { In-house development of } \\
\text { proprietary systems with } \\
\text { traditional ERP system for } \\
\text { intra-integration }\end{array}$ & $\begin{array}{l}\text { Advanced IS/IT } \\
\text { ERP merged with other new } \\
\text { functional modules }\end{array}$ & $\begin{array}{l}\text { Sophisticated Web-based } \\
\text { technologies }\end{array}$ \\
\hline
\end{tabular}


The authors suggests that VIEs, EEs and VEs should be thought of as an evolving continuous strategy for the enterprization of operations, and not manifestations of separate different strategies as strategy, structure and operations respond to changing business requirements (Binder and Clegg, 2007) - as demonstrated by the case study later in this paper. We suggest that there is a trend for vertically integrated enterprises to be replaced by extended enterprises (Daniels, 1998) and extended enterprises to be replaced by virtual enterprises whenever increased flexibility is required; or to put it another way "opportunistic aggregations of smaller [business] units come together and act as though they were a larger, longer-lived enterprise" (Goranson, 1999, p.65). This increasingly occurs as firms seek to temporise strategy and structure to pre-empt changes in uncertain business environments. Thus the trends concerning ERP development and enterprise management practice must be understood better if sustainable competitive advantage is to be achieved through the enterprization of operations.

\section{Enterprise Resource Planning Systems and Collaborative Enterprise Governance}

This section proposes tentative correlations between ERP and enterprise types described above, as summarised by Figure 1, which are precursors to the induction of a new conceptual contingency model given later in this paper.

Figure 1. Tentative correlations between ERP system types and enterprise types based on extant literature. 


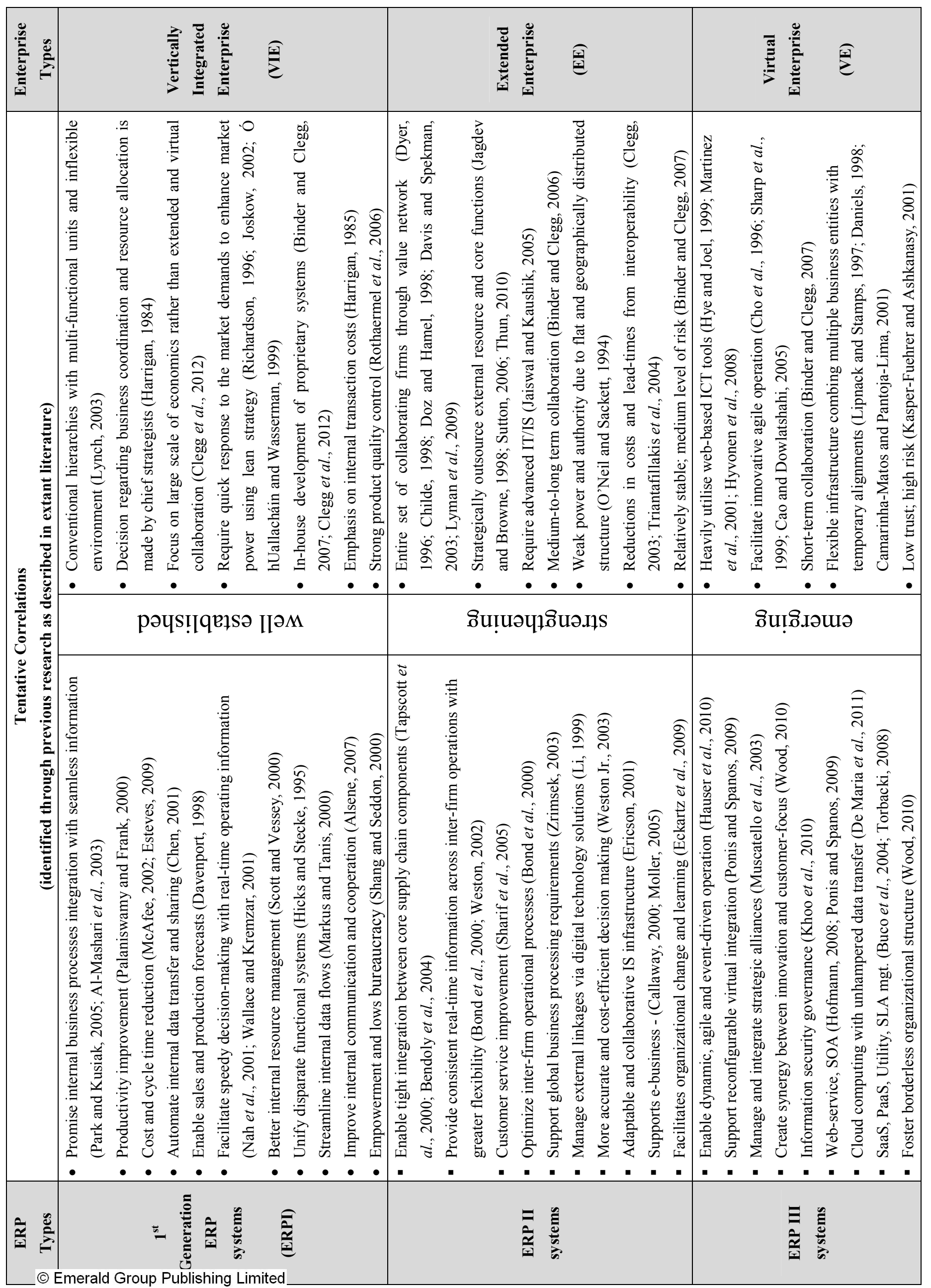

This is a pre-print of a paper and is subject to change before publication. This pre-print is made available with the understanding that it will not be reproduced or stored in a retrieval system without the permission of Emerald Group Publishing Limited. 
Figure 1 proposes tentative correlations, as shown by the arrows, from a literature review. Overall a strong positive correlation was found between ERP and VIE, and between ERPII and EE. Emerging publications on post-ERPII systems (a.k.a. ERPIII) were fewer but correlate ERPIII with VEs (see the two main columns in Figure 1 for the key works on which these correlations are based).

Some research also makes weaker correlations between ERP and EE (McAfee, 2002; Davenport, 1998; Nah et al., 2001) and ERPII to VIE (Henningsson and Carlsson, 2011; Weston, 2002; Eckartz et al., 2009), as well as between ERPII to VE (Bala and Venkatesh, 2007; Tapscott et al., 2000; Bond et al., 2000; Li, 1999; Ericson, 2001) which discuss how a continuum of strategic operations, structural and ERP changes are observable in response to factors in the business environment. Particularly interesting is the transition towards ERPIII and VE adoption, which maybe because ERPIII packages are expected to be cheaper and deployment of them easier, quicker and more flexible. This may be because technologies upon which they are based (e.g. SOA, SaaS, or PaaS) become more mature in terms of security, robustness and usability (Ponis and Spanos, 2009; Rodon et al., 2011; Olsen and Sætre, 2007; Vathanophas, 2007; Hofmann, 2008; Buco et al., 2004). Users of VEs and ERPIII systems are hoping for a quick-to-create and quick-to-dismantle enterprise whose operations enable fast and accurate transactions in risky open environments (Browne and Zhang, 1999).

\section{Established Frameworks for ERP and IS Conceptualization}

The authors use Binder and Clegg's (2006) a priori Collaborative Enterprise Governance (CEG) concept to explain correlations between ERP IS and enterprise management; in particular the Dynamic Enterprise Reference Grid (DERG) which is shown in Figure 2. The DERG is taken as one point of departure from established frameworks in the field. We use the DERG because it describes each type of enterprise in detail (based on Table 2's definitions) and explains how changes occur based on the degree of 'engageability' (Binder and Clegg, 2006) or attractiveness to others (note: 'engageabilty' is derived from the longevity of a planned relationship, the availability of resources, transaction costs, asset specificity, and degree of process and IS integration - see 
bullet points in Figure 2).

The DERG (Figure 2) summarizes each enterprise type mentioned above (VIE, EE, VE) as well as a defunct enterprise (an enterprise that does not operate as it should) classified by their current and future potential engageability. These structures are thought to be a continuum of an operations strategy manifesting itself as different structures in response to contingent factors in the business environment. Figure 2's solid arrows show proactive planned changes, and broken arrows show unplanned changes in reaction to changes in the business environment.

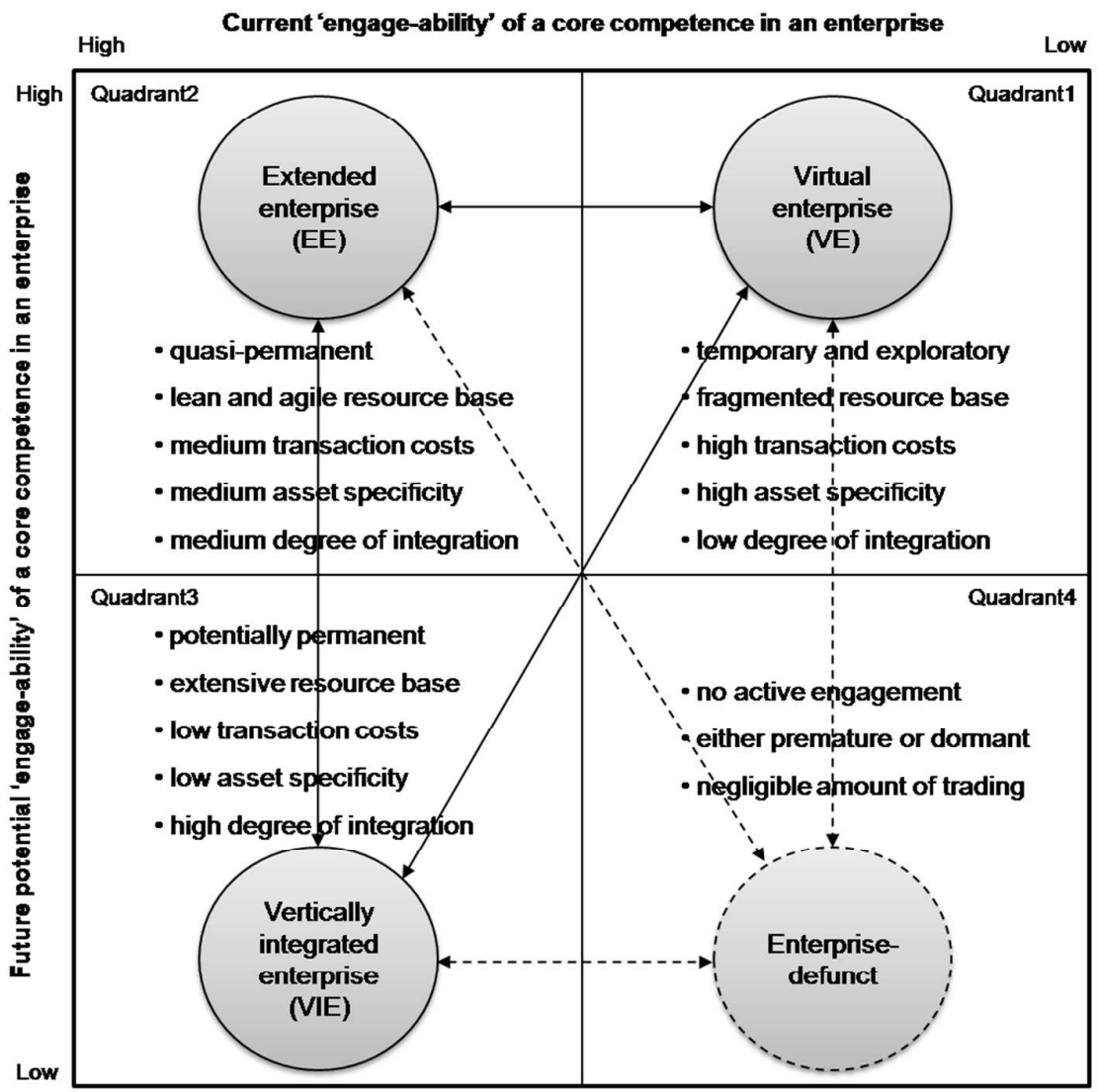

Figure 2. Dynamic Enterprise Reference Grid (DERG) - used in Collaborative Enterprise Governance (Binder and Clegg, 2006)

Despite its insight into enterprise and operational strategy and structure the DERG in its current form is limited, because it does not explicitly consider IS strategy (e.g. ERP strategy). Thus Galliers' (1994) a priori 'IS Strategy Formulation' model (see Figure 3) is used to extend the 
DERG as Galliers' model presents IS transformations which complements the DERG; as illustrated by the case study later in this paper.

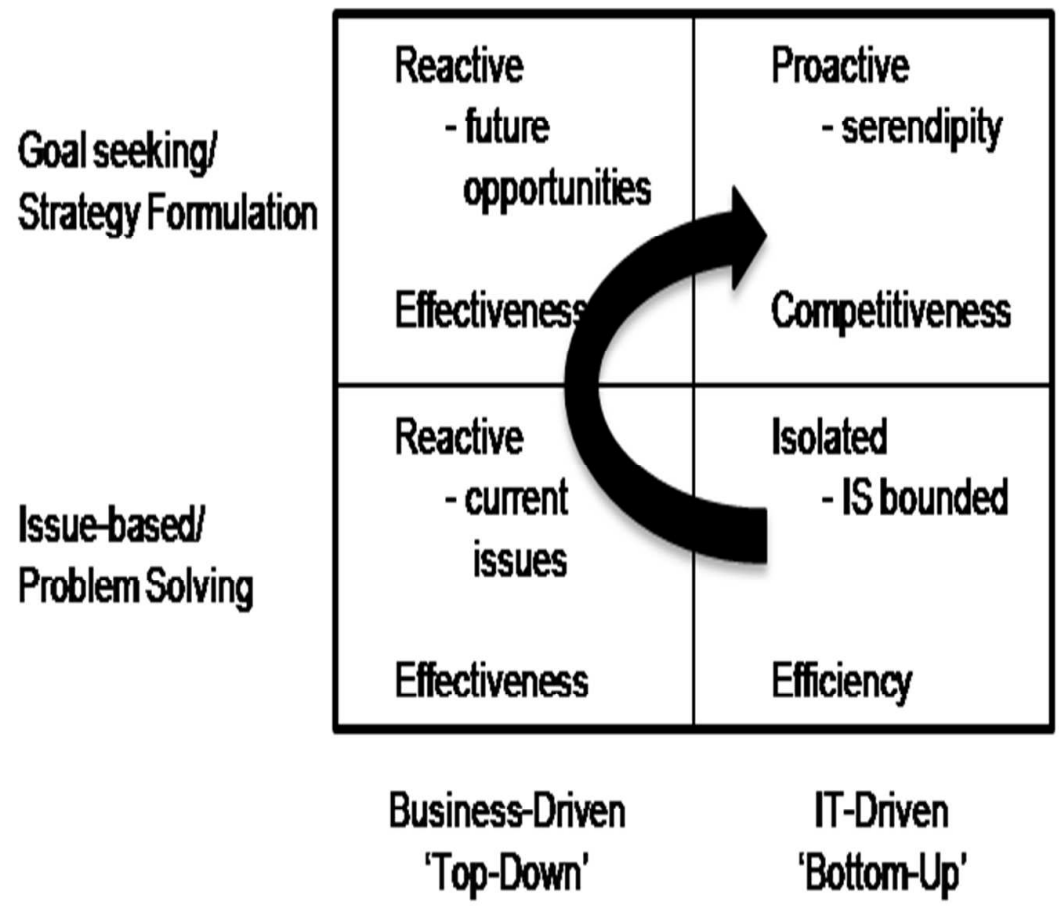

Figure 3. IS Strategy Formulation Model (Galliers, 1994)

Complementarity between these two models occurs because Binder and Clegg's DERG does not explicitly explain IS strategy; and Galliers' model does not explicitly address Collaborative Enterprise Governance (a.k.a. enterprise strategy and structure). Hence Galliers' model is taken as another point of departure from established concepts in the field. These are in addition to Binder and Binder and Clegg's DERG and a summary correlation of ERP types (Table 1) and Enterprise Types (Table 2) as seen in Figure 1. These points of departure are used to induct the new contingency framework given towards the end of this paper (objective iii) which is illustrated by using new empirical data; the collection of which is now described in the research methodology section below. 


\section{RESEARCH METHODOLOGY}

The Collaborative Enterprise Governance (CEG) concept, as shown in Figure 4, was used to build an empirical case study because it considers an enterprise to be made up of parts of different companies; where each part is built around highly specific competencies (e.g. physical resources and intangible knowledge) integrated with other less specific capabilities (e.g. processes and IS) (Binder \& Clegg, 2007); thus making it suitable to investigate ERP and enterprise management trends.

The CEG concept uses tools that fall into four stages. Stage 1 uses the 'Enterprise Matrix' to codify and map an enterprise which is a template for data collection based upon King's (King, 2004) Template Analysis technique. Stage 2 uses theories discussed previously (i.e. enterprise theory, ERP and IS strategy) to analyse, codify and define the enterprise and ERP type being investigated, as given in Tables 1 and 2. Stage 3 uses the Dynamic Enterprise Reference Grid (DERG) (as in Figure 2) to forecast where the enterprise might be heading, and Stage 4 assesses the options for change (i.e. IS and enterprise strategies). CEG is cyclical, so therefore, the final stage re-initiates Stage 1 as change is assumed to be perpetual.

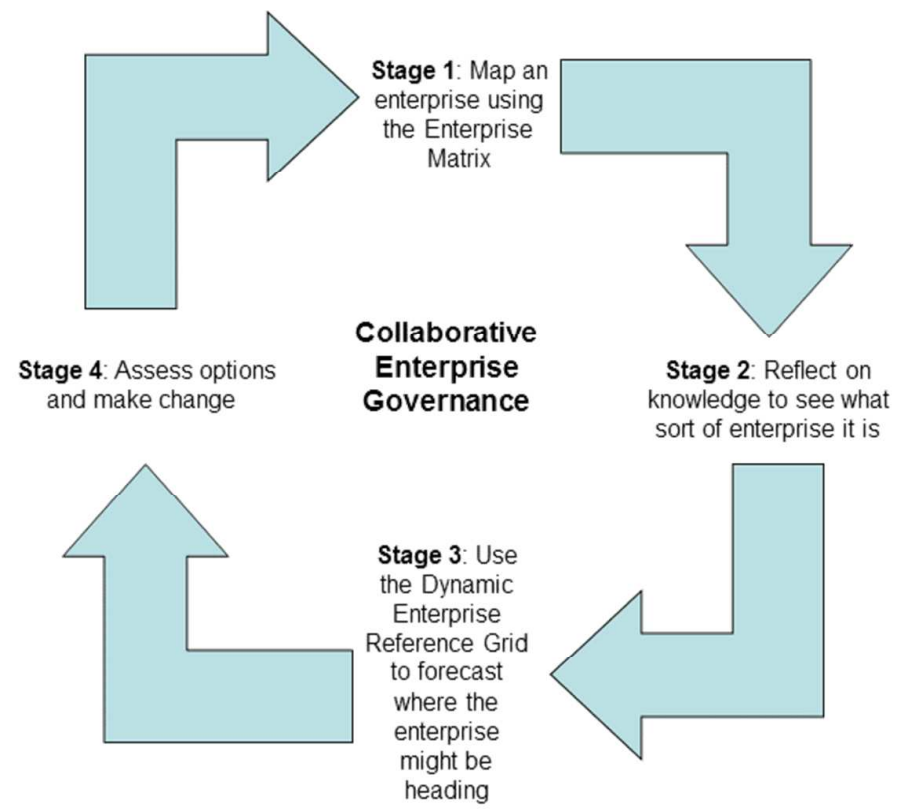

Figure 4. The Collaborative Enterprise Governance (CEG) concept (Binder and Clegg, 2007). 
The CEG concept was applied to a Chinese manufacturing company - Zoomlion - over a two year period; this company was carefully selected as they were known to be innovative and were adopting a strategy to grow quickly through their use of ERP systems and close collaboration with other organisations (a.k.a. the enterprization of operations). Zoomlion interviewees were chosen because they were or had been actively involved in strategic operational and IS changes. The Zoomlion case study details (enterprise matrices, reflection on knowledge, use of the DERG and strategic options) are given in this paper which illustrates one possible path through the DERG in response to specific management decisions made at Zoomlion.

\section{CEG Stage 1: Mapping Zoomlion's Enterprise}

Longitudinal data were collected from Zoomlion employees between 2009-2011 via documentation, observation and semi-structured interviews as defined in Table 3 ( $>100$ pages of transcribed notes) to explore the key characteristics of ERP (as in Table 1) and enterprises (as in Table 2). All the data were then summarised and structured into a template as per Template Analysis (King, 2004); CEG refers to these templates as the enterprise matrices. Data were collected over a two year time period to enable a longitudinal study to be conducted to show the dynamic changes in strategy, structure and IS. 
Table 3. Details of interviewees from Zoomlion

\begin{tabular}{|c|c|c|c|}
\hline Role of interviewee & $\begin{array}{l}\text { Reason for selection - major enterprise } \\
\text { management and IS events discussable }\end{array}$ & $\begin{array}{l}\text { No. and average } \\
\text { length of interviews }\end{array}$ & $\begin{array}{c}\text { Interview } \\
\text { period }\end{array}$ \\
\hline Chief Executive Officer & Business strategy with IS/IT implementation & $3 \times 1.5 \mathrm{hrs}$ & $2009-2011$ \\
\hline Chief Information Officer & $\begin{array}{l}\text { Information systems infrastructure } \\
\text { ERP project adoption and management }\end{array}$ & $3 \times 2 \mathrm{hrs}$ & $2009-2011$ \\
\hline $\begin{array}{l}\text { IS/IT and ERP project } \\
\text { team/department }\end{array}$ & $\begin{array}{l}\text { Explore people issues related to ERP systems } \\
\text { implementation }\end{array}$ & $3 \times 1.5 \mathrm{hrs}$ & 2009 \\
\hline IT/IS and ERP project manager & $\begin{array}{l}\text { Explore technical and managerial issues related to } \\
\text { ERP systems implementation } \\
\text { ERP vendors and IT/IS partners } \\
\text { Chronology of ERP systems development }\end{array}$ & $3 \times 2 \mathrm{hrs}$ & $2009-2011$ \\
\hline $\begin{array}{l}\text { Production line and supply chain } \\
\text { manager }\end{array}$ & $\begin{array}{l}\text { Operational business processes } \\
\text { Relationships with suppliers and customers }\end{array}$ & $2 \times 1.5 \mathrm{hrs}$ & 2009 \\
\hline Executive manager & $\begin{array}{l}\text { Human resource management } \\
\text { Business strategy and development }\end{array}$ & $2 \times 1.5 \mathrm{hrs}$ & 2011 \\
\hline Logistics manager & $\begin{array}{l}\text { Inventory management } \\
\text { Upstream control of supply chain } \\
\text { Transportation control }\end{array}$ & $2 \times 2 \mathrm{hrs}$ & 2011 \\
\hline Marketing and sales manager & Marketing and product development & $2 \times 1.5 \mathrm{hrs}$ & 2011 \\
\hline
\end{tabular}

From Zoomlion's data it was possible to produce two enterprise matrices at different time periods showing different dynamic transitions.

\section{CEG Stage 2: Reflect on Knowledge to determine the type of Enterprise}

Through the process of building and validating two enterprise matrices Zoomlion's enterprise was analysed, typified against enterprise types (defined in Table 2) and transitions past, current and planned investigated. Two transitions in Zoomlion became apparent; these were (i) a move from a defunct enterprise into a vertically integrated enterprise, followed by (ii) a move from a vertically integrated enterprise into an extended enterprise - as discussed in the case study. 


\section{CEG Stage 3: use the DERG to forecast where the Enterprise may be heading}

Enterprise transitions over time were analysed using multiple matrices in a longitudinal study allowing a path of strategic decisions to be plotted. The Zoomlion DERG is shown later in the case study showing two past transitions (from Time 1 to Time 2, and from Time 2 to Time 3 ) and a potential future transition (from Time 3 to Time 4).

\section{CEG Stage 4: Assess Options and make Change}

From analyses done in CEG Stages 3 and 4 a strategic vision for Zoomlion's enterprization of operations can be seen, as Zoomlion plans to become a sustainable and agile enterprise, through more effective interactivity of operations, IS and structural strategic thinking with their suppliers partners and customers.

\section{CASE STUDY: ZOOMLION}

Zoomlion was founded as the Heavy Industry Science \& Technology Development Company Ltd. in 1992. Its headquarters are in Changsha and its main manufacturing plant is located in mainland China. Initially Zoomlion was a hi-tech public company producing cranes and other machines for the manufacturing and construction fields, with nearly 20,000 employees spread across many different separate businesses. At present, Zoomlion's production line serves China and the Western World, and the company has also now become a multi-national manufacturer of consumer products, with a market capitalization of nearly \$1BN USD in 2010. Zoomlion has its own international sales network, management systems for technical development, manufacturing processes and logistics. Zoomlion has achieved rapid development by building up a knowledge-based learning enterprise; and producing quality innovative products with enhanced services delivered to end-users. Zoomlion's case is now discussed in detail with respect to Galliers' IS Strategy Formulation Model and Binder and Clegg's Collaborative Enterprise Governance (CEG). It focuses on the manufacture of Cranes. 


\section{Shifting from a Defunct Enterprise (T1) into a Vertically Integrated Enterprise (T2)}

Zoomlion was founded within a high-tech academic institution and could initially be considered as a 'defunct enterprise' because it was isolated and without any directly profitable activity (at 'Time

1' - T1 - circa 1992). During its transformation from academe into a commercial manufacturing enterprise the management team realized that electronic information systems must replace the present inefficient physical data flows used in its processes, which caused delays and added unnecessary cost. Thus, IT applications were adopted gradually but with limited initial impact. In parallel, Zoomlion merged with other peer companies that supplied logistic and ancillary products/services in order to decrease cost of sales and increase product differentiation. This was achieved through vertical integration (VI) with some of its competitors in the same industry creating a larger scope and scale of economy, which in turn decreased competitive rivalry and strengthened Zoomlion's bargaining power with its suppliers and customers.

As per CEG Stage 1, an Enterprise Matrix was used to capture structured data and map Zoomlion's operations and determine its enterprise structure circa 1999 (at T2); this is shown in the Enterprise Matrix in Table 4 revealing Zoomlion's value stream (a.k.a. a chain of cross-company value adding activities) for cranes, its enterprise members, and what each member does in every stage of the value stream. 
Table 4. Enterprise Matrix for Zoomlion - transforming from Defunct Enterprise (T1) into VIE (T2).

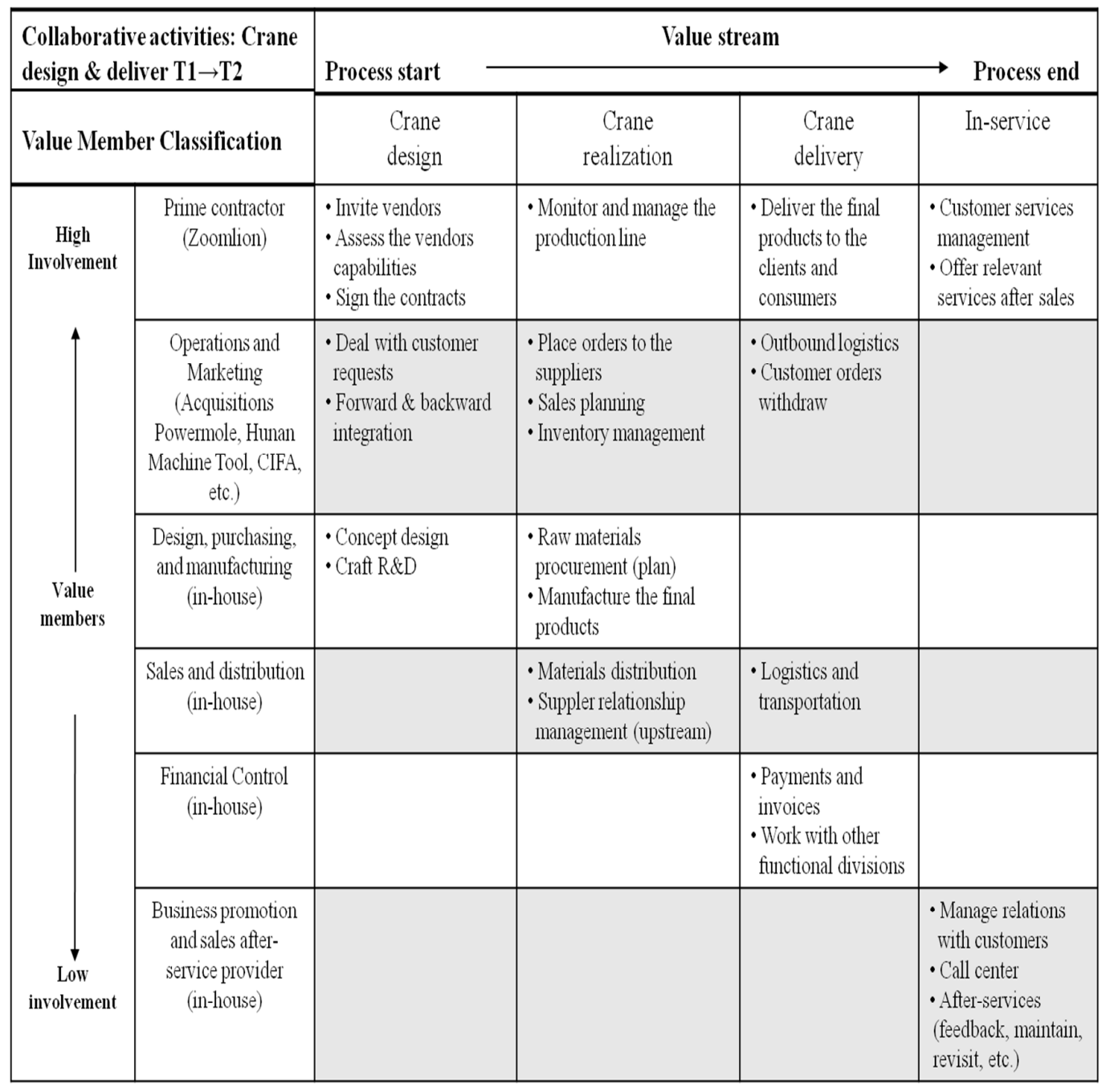

As shown in Table $4\left(3^{\text {rd }}\right.$ line down), Zoomlion is a prime contractor (at T2) and was in an influential position by being able to issue primary contracts, control production and influence product development and distribution of the cranes. The operations department worked with merged and acquired firms (e.g. Powermole, CIFA) through backwards and forwards integration to process customer orders, place orders on suppliers and manage outbound logistics (Table $4 ; 4^{\text {th }}$ line down). New cranes were designed by the R\&D division, raw materials were planned to be purchased by the logistics department and delivered to warehousing and manufacturing. The financial department, cooperating with other functional branches focused on payments and invoices of all transactions. Zoomlion also established a 'call centre' for managing customer relationships better (Table $4 ; 5^{\text {th }}, 6^{\text {th }}, 7^{\text {th }}$ and $8^{\text {th }}$ lines down). 
Zoomlion's rapid change also meant that a number of incumbent information systems had become isolated and outdated. To improve the situation Zoomlion launched a single integrated ERP system to revamp its outdated IS assets and in doing so embrace enterprise management concepts more widely. During implementation, the new ERP system enabled Zoomlion to dramatically re-design its business processes focusing on high-value internal departments and greater integrative potential with its external customers and suppliers. Thus, by T2, a vertically integrated enterprise (VIE) and management aspirations to become even more enterprise conscious were observed.

\section{Shifting from a Vertically Integrated Enterprise (T2) into an Extended Enterprise (T3)}

Despite rapid growth Zoomlion was also experiencing unpredictable market behaviour and worked hard to imbibe new IS assets into the enterprise. For its next strategic developments establishing a stronger enterprise-conscious IS strategy was imperative in order to increase inter-company communication and efficiency. For this purpose, the management team sourced and allocated new members into their extending enterprise which further enhanced Zoomlion's revised enterprise-wide vision and mission (see Table 5, representing T3, circa 2003). The marked change from previous strategy was that the enterprise members were considered to be within Zoomlion's re-engineered enterprise boundaries and provided essential core capabilities connected through shared information systems and processes. Now Zoomlion's enterprise more closely represented an extended enterprise rather than a vertically integrated one.

Specifically at T3 (as in Table 5) Zoomlion worked with CIFA who offered advanced technologies and skilled knowledgeable people to assist with crane design and logistics in Western countries (Table $5 ; 4^{\text {th }}$ line down). Chassis and hydraulic components were also provided by Mercedes Benz, KHI and Rexroth respectively for crane realization through medium-long term collaboration (Table $5 ; 5^{\text {th }}, 6^{\text {th }}, 7^{\text {th }}, 8^{\text {th }}$ line down). Direct communication between Zoomlion and suppliers (e.g. HNNFE, KHI), vendees (e.g. Lanye), clients and third-parties were achieved via ERP systems offered by SAP (managed by consulting company IBM) along with other core systems (e.g. Product Life Management (PLM) and Manufacturing Execution System (MES) supported by Siemens) (Table 5; $9^{\text {th }}, 10^{\text {th }}, 11^{\text {th }}, 12^{\text {th }}$ line down) all these activities being core to Zoomlion's operations. The financial 
division also was now become enterprise-conscious and increasingly concerned with external business links, rather than just focusing on back-office transactions as before (Table $5,13^{\text {th }}$ line down). All of these are characteristics of an EE rather than a VIE which had preceded.

Table 5. The Enterprise Matrix for Zoomlion - transforming from VIE (T2) into EE (T3)

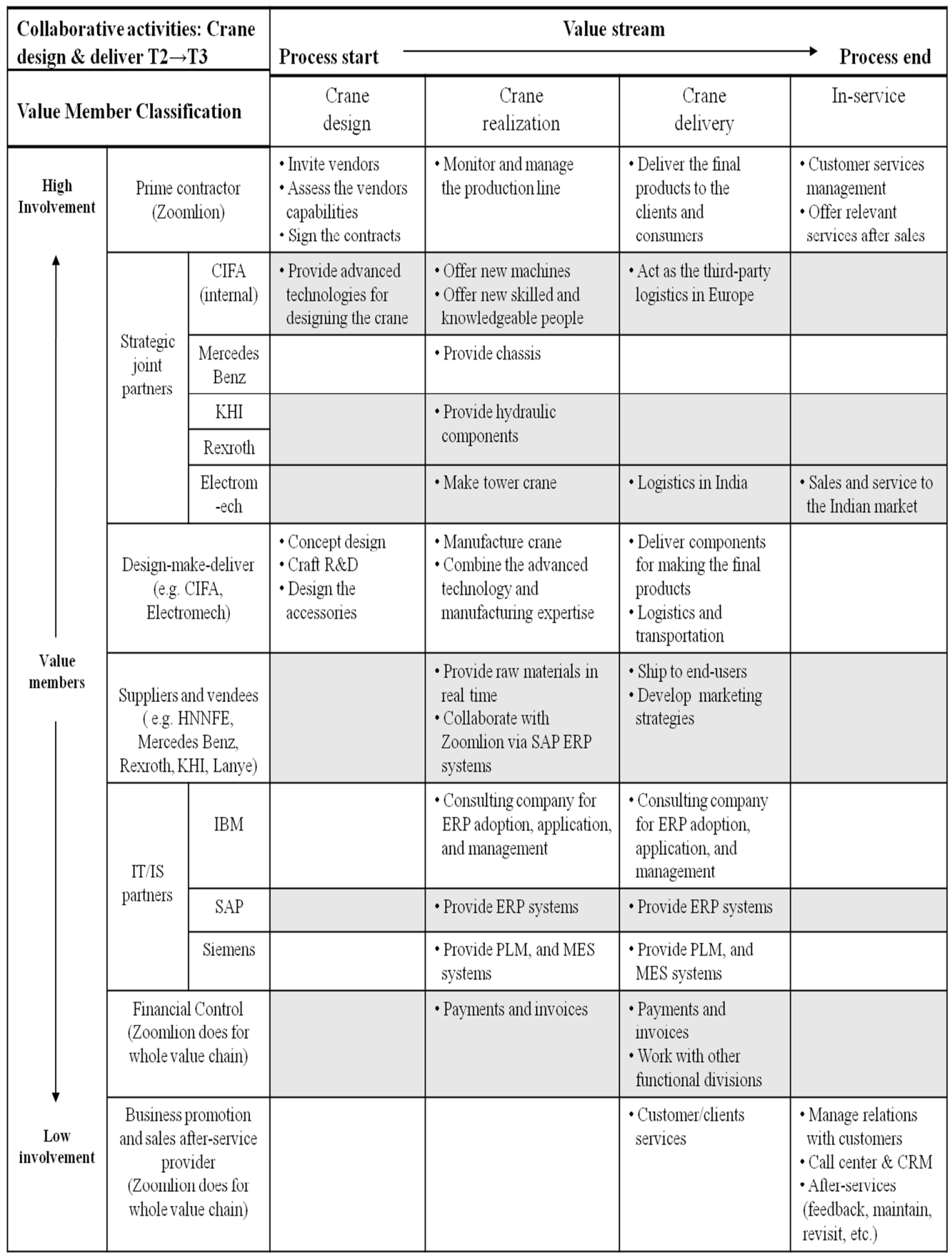




\section{Shifting from an Extended Enterprise (T3) towards a Virtual Enterprise (T4)}

The asset specificity of Zoomlion's highly integrated ERP system, whilst now enhancing internal process efficiency, was also beginning to hinder its proactivity towards future dramatic changes in the business environment as it was entrenching the status quo. Moreover, the company increasingly needed to consider its private sector suppliers and consumers critical to enterprise performance. Hence, at T3, Zoomlion could be now thought of as an extended enterprise, with medium degrees of inter-firm integration, with moderately lean and agile resources (e.g. more efficient process design and stock management policies) and wider embryonic alliances forming with other companies intending to further innovate its products, processes and people practices.

At this point Zoomlion has constantly maturing SCM and CRM ERP functionalities which are increasingly linked with other organisations' operations which drives Zoomlion towards a future virtual enterprise concept (at T4). Consequently this should enable Zoomlion to more deeply and effectively tap into its wider enterprise's resources via increased functional scope and scalability in the key elements relating to ERP systems and collaborative enterprise governance (as defined in Tables 1 and 2 respectively). In this scenario, at T4, Zoomlion is approaching the use of ERPIII type information systems and the virtual enterprise strategy, operations and structure.

\section{Summarizing Zoomlion's Transitions using the Dynamic Enterprise Reference Grid (DERG)}

Figure 5 summarizes the transformational route experienced by Zoomlion as it shifted from a defunct enterprise (at T1) with limited IT usage, into a vertically integrated enterprise (at T2) using a traditional ERP system. Subsequently, the intra-enterprise (a.k.a. inter-firm) operations strategy evolved the VIE (at T2) to an EE (at T3) as the enterprise resource planning system developed from traditional ERP into an ERPII system, which in turn assisted the company to gain more competitive advantage through strategic outsourcing and mutual partnerships. Finally to improve its virtual co-operations and interoperability Zoomlion is currently (circa 2011) developing VE concepts to accompany the adoption of future ERPIII type systems (i.e. a move from T3 towards T4) to enhance the enterprization of their operations. 


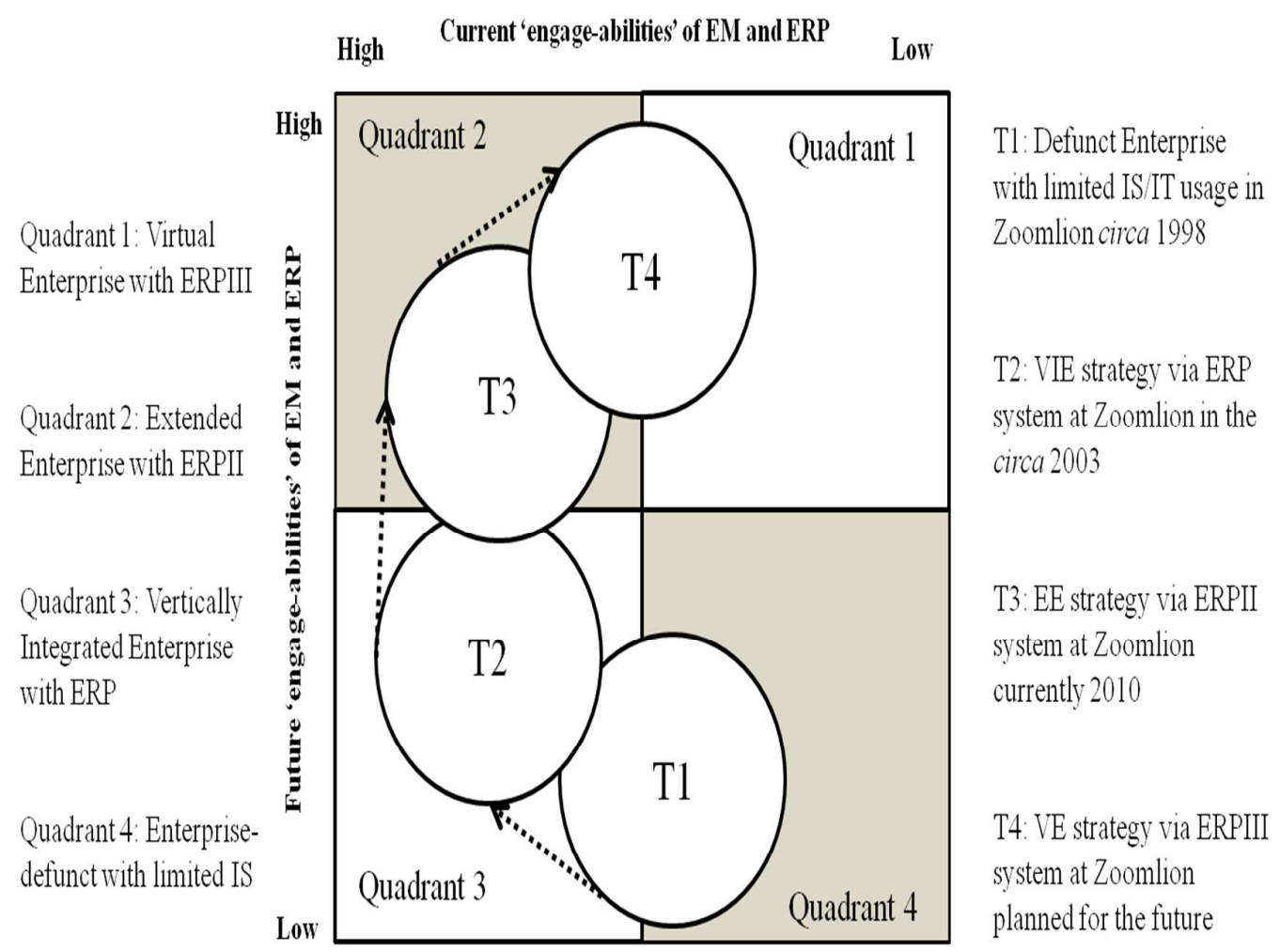

Figure 5. The Dynamic Enterprise Reference Grid (DERG) showing the Transformational route of Zoomlion.

\section{DISCUSSION OF THE GENERALIZABLE FINDINGS: THEORY AND PRACTICE}

Figure 6 is a summary of the generalizable findings from the above Zoomlion case study presented as a contingency framework known as the Dynamic Enterprise Resource Grid for ERP (DERG-ERP) which demonstrates how Binder and Clegg's CEG (2007) and Galliers' IS Strategy Formulation Model (1994) have been combined to guide the interactions between enterprise resource planning and the management of enterprises; the authors believe it is a valuable and significant generalizable conceptual deliverable from this research. 


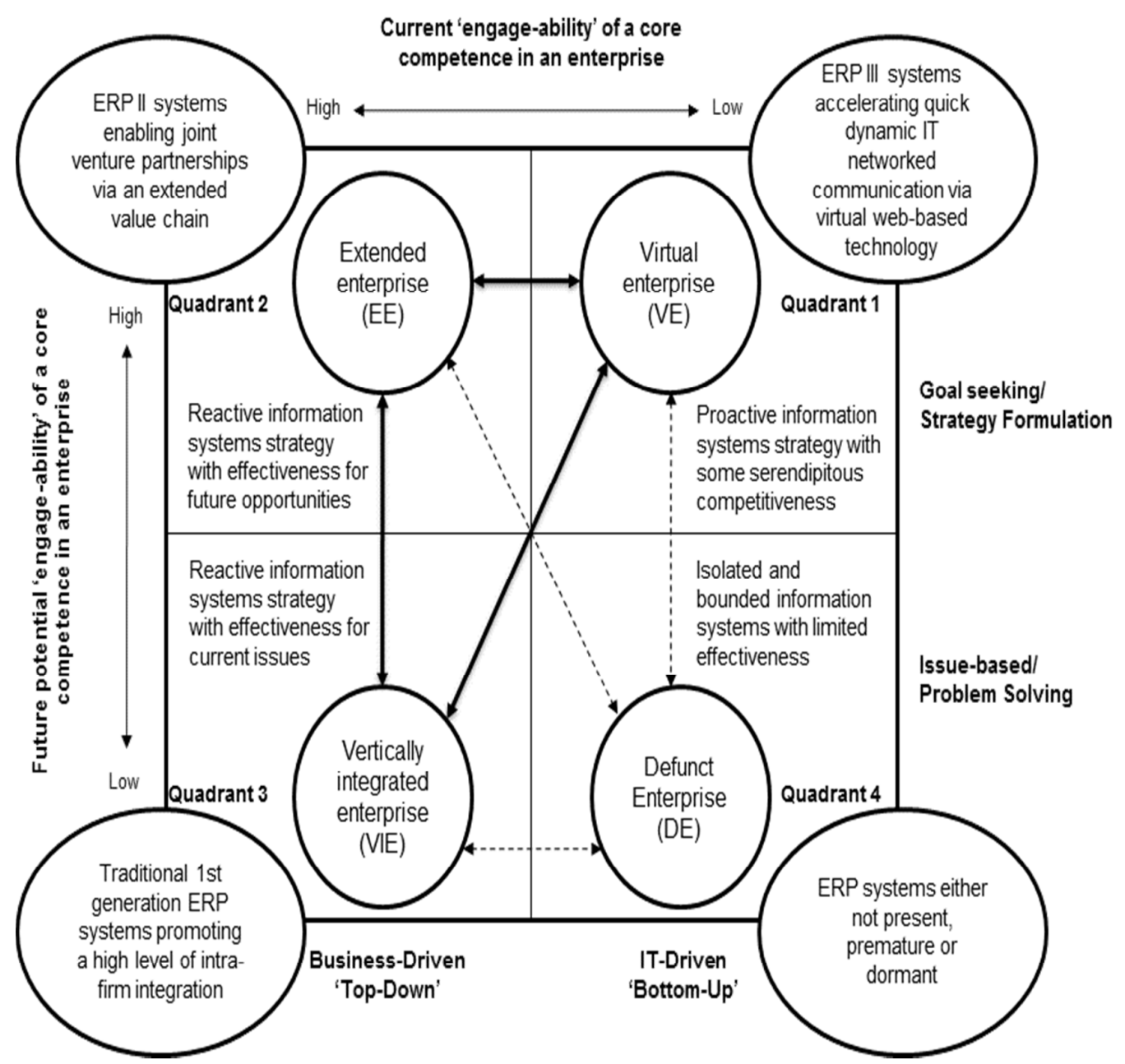

Figure 6. Dynamic Enterprise Reference Grid for Enterprise Resource Planning (DERG-ERP).

The Dynamic Enterprise Reference Grid for Enterprise Resource Planning (DERG-ERP) as shown in Figure 6 is now described generically quadrant by quadrant.

\section{Traditional ERP(I) Systems use in Vertically Integrated Enterprises}

In Quadrant 3 of the DERG-ERP in Figure 6 a VIE would be most appropriate using an ERPI system which can support all core processes and provide some inter-departmental integration. Such systems are relatively good at long term issue based (or detailed problem solving) tasks and help accomplish business driven top-down goals, although they do not contribute directly towards the strategic forward vision of a company because they are usually operational and transactional in 
nature; and so therefore tend to entrench current practice and become relatively reactive to strategic and environmental business changes, rather than being the driver of flexibility or change. ERPI performs best when core competencies of strategic partners in an enterprise are currently highly engaged but could decline in attractiveness in the future; thus allowing transaction costs to be minimised and scale of economy to be maximised.

\section{ERPII Systems use in Extended Enterprises}

In Quadrant 2 of the DERG-ERP in Figure 6 an EE is most appropriate. The EE best serves medium-to-large sized operations aspiring to form closer partnerships within an extended value chain. ERPII systems are able to extend ERPI capabilities to cover supply chain management and customer relationship functions to encourage active participation from other legal entities. ERPII systems can therefore drive business driven top-down tasks which can be directly used for achieving goals and formulating strategy across company boundaries (e.g. supply chain policies and collaborative forecasting with suppliers). ERPII is most effective when core competencies of strategic partners in an enterprise are currently, and in the near future, highly engaging and therefore highly likely to be needed in new collaborations, with new modus operandi.

\section{ERPIII Systems use in Virtual Enterprises}

In Quadrant 1 of the DERG-ERP in Figure 6 a VE is shown. The VE best serves organisations which have aspirations for rapid growth (and so are likely to be relatively small) and see themselves as innovative and likely to be serial and parallel innovators or collaborators. ERPIII systems are able to facilitate temporary and highly agile operations using non-proprietary web-based technology for computer integrated manufacturing systems with decentralised operational control on a global scale and scope. ERPIII systems can therefore be used strategically to achieve strategic goals whilst still incorporating incremental IT driven changes required by bottom-up idiosyncrasies (Olsen and Sætre, 2007). ERPIII systems are considered to be pro-active information systems with some almost serendipitous qualities (e.g. cloud-sourcing of innovative 
ideas) which fit well to this enterprise type as long as the required security and trust-levels can be attained.

ERPIII applications are best used in enterprise-wide operations within and across different legal entities (i.e. parts of companies). Based on traditional ERP and ERPII principles, ERPIII based enterprises will probably achieve the next level of business integration; namely to enable a strategic-level dialog between customers/potential customers, an enterprise integrator, and the extended supply chain using SOA, PaaS, SaaS technologies and SLA management tools; and will most likely be maintained by a strategic IT/IS partner. Moreover ERPIII type solutions could create truly integrated and borderless enterprises; thus reaching near utopian levels of enterprise consciousness bringing about the simultaneous strengthening of operations, strategy and IT interactivity, which the authors refer to as the 'enterprization of operations'.

\section{Defunct Enterprises and Information Systems Misuse}

Quadrant 4 of the DERG-ERP in Figure 6 shows a defunct enterprise (DE). DE's occur when operations strategy, structural thinking, or IS policy have gone wrong or are premature; the challenge for operators and strategist in this business environment is to move to another more suitable type of enterprise as quickly as possible. In DEs enterprise resource planning is often not widely used, used inappropriately or without any great effectiveness. Tasks are normally driven by bottom up information technology initiatives lacking strategic congruence.

\section{Putting it all together: theory and practice into a usable concept}

A structured recapitulation of the research presented above is given in tabular format in Table 6 which describes the 'static' typologies of enterprises, 'dynamic' changes they may undergo, provenance from literature, and an empirical illustration using Zoomlion (as per Figure 5). 
Table 6: An Illustration of the new DERG-ERP concept using Zoomlion and links to literature

\begin{tabular}{|c|c|c|c|}
\hline \multicolumn{2}{|c|}{$\begin{array}{l}\text { DERG-ERP conceptual } \\
\text { element (objective iii) }\end{array}$} & \multirow[b]{2}{*}{$\begin{array}{l}\text { Provenance from literature on theory } \\
\text { (objectives } \mathrm{i} \text { and } \mathrm{ii} \text { ) }\end{array}$} & \\
\hline Static & Dynamic & & $\begin{array}{c}\text { Illustration from } \\
\text { empirical research } \\
\text { (objective iv) }\end{array}$ \\
\hline $\begin{array}{l}\text { Quadrant } 1 \\
\text { Virtual enterprise } \\
\text { (VE) with ERPIII }\end{array}$ & & $\begin{array}{l}\text { - ERPIII contains a flexible, agent-based ICT architecture } \\
\text { - Quick and dynamic inter-firm collaboration through business process } \\
\text { - Psychological issues such as trust and conflict are critical success } \\
\text { factors } \\
\text { - Flexible, agility, loose, temporary and dynamic project based } \\
\text { collaborative venture } \\
\text { - ERPIII systems accelerate quicker and more dynamic business } \\
\text { network communication } \\
\text { - Assisted by SOA, cloud computing, PaaS, SaaS and other web-based } \\
\text { tools. } \\
\text { - Potential high risk with fragmented resource base } \\
\text { - High transaction cost } \\
\text { - High inter-enterprise integration }\end{array}$ & $\begin{array}{l}\text { This is the future enterprise } \\
\text { management (EM) and IS } \\
\text { strategy for Zoomlion }\end{array}$ \\
\hline $\begin{array}{l}\text { Quadrant } 2 \\
\text { Extended } \\
\text { enterprise (EE) } \\
\text { with ERPII }\end{array}$ & & $\begin{array}{l}\text { - Enterprise strategy changes into goal seeking rather than issue-based } \\
\text { - Medium transaction cost with relatively lean resource base } \\
\text { - ERP for medium degree of intra-enterprise integration } \\
\text { external operational processes } \\
\text { - Moderate supplier-customer relationships and collaborative alliances } \\
\text { are managed by SCM/CRM systems approaching the virtual value } \\
\text { chain concept } \\
\text { - More stable, strategic, close and permanent collaborative venture } \\
\text { focused }\end{array}$ & $\begin{array}{l}\text { Zoomlion adopted a new } \\
\text { business strategy to } \\
\text { re-position its value members: } \\
\text { joint partners, suppliers, } \\
\text { customers, and even } \\
\text { competitors. Meanwhile, lean } \\
\text { management concept and } \\
\text { strategic outsourcing from } \\
\text { CIFA and Powermole is } \\
\text { applied }\end{array}$ \\
\hline $\begin{array}{l}\text { Quadrant } 3 \\
\text { Vertically } \\
\text { integrated } \\
\text { enterprise (VIE) } \\
\text { with traditional } \\
\text { ERP }\end{array}$ & & $\begin{array}{l}\text { - Proprietary ERP supposedly built upon real-time information } \\
\text { - High degree of functional units integration involving predominantly } \\
\text { production processes } \\
\text { - Potentially permanent with high degree of intra-integration } \\
\text { - Promotes business process re-engineering } \\
\text { - Extensive internal resource and low transaction cost } \\
\text { - ERP used reactively } \\
\text { - Business strategy is driven by 'top-down' approach }\end{array}$ & $\begin{array}{l}\text { After ERP systems launch } \\
\text { Zoomlion had a high level of } \\
\text { intra-integration. } \\
\text { Also, large contributions are } \\
\text { noted from value members } \\
\text { who engaged within intra-firm } \\
\text { activities }\end{array}$ \\
\hline
\end{tabular}




\begin{tabular}{|c|c|c|c|}
\hline $\begin{array}{l}\text { Quadrant } 4 \\
\text { Defunct enterprise } \\
\text { with limited IT/IS } \\
\text { efficiency }\end{array}$ & & $\begin{array}{l}\text { - No profits achievable } \\
\text { - Rare IT/IS implementation or no ERP } \\
\text { - Fixed single company configuration } \\
\text { - No active engagement in a current collaborative activity } \\
\text { - IT driven strategy via 'bottom-up' approach } \\
\text { - Company focuses on solving 'issues-based' problems }\end{array}$ & $\begin{array}{l}\text { Zoomlion is initially founded } \\
\text { on a high-tech academic } \\
\text { institution without any } \\
\text { explicit profitable or } \\
\text { commercial purposes }\end{array}$ \\
\hline & $\begin{array}{l}\text { Quadrant } 4 \text { to } \\
\text { Quadrant } 3 \\
\text { From DE to VIE } \\
\text { by using ERP }\end{array}$ & $\begin{array}{l}\text { - Transforming from single organization into enterprise accompanied } \\
\text { with emerging commercial activities } \\
\text { - Moderate collaboration is required but mainly focusing on the internal } \\
\text { operations } \\
\text { - Commence to implement traditional ERP system or similar IT/IS tools } \\
\text { to attain a high intra-integration } \\
\text { - Shifting from IT-driven 'bottom-up' approach into 'top-down' policy } \\
\text { driven by business strategy }\end{array}$ & $\begin{array}{l}\text { Zoomlion started off as an } \\
\text { academic institution (DE) } \\
\text { with limited IT/IS usage and } \\
\text { then shifted into VIE using a } \\
\text { traditional single integrated } \\
\text { ERP systems to achieve high } \\
\text { efficient operations and gain } \\
\text { more market profits }\end{array}$ \\
\hline & $\begin{array}{l}\text { Quadrant } 3 \text { to } \\
\text { Quadrant } 2 \\
\text { From VIEs to } \\
\text { EEs by } \\
\text { developing ERP } \\
\text { to ERPII }\end{array}$ & $\begin{array}{l}\text { - Business processes are re-engineered and lean thinking must be } \\
\text { adopted in parallel } \\
\text { - The most valuable members who engaged in the entire value chain } \\
\text { have transferred from outside the company boundary to inside the } \\
\text { enterprise boundary } \\
\text { - A new strategic partnership has revived an existing and proven } \\
\text { enterprise module by deploying it in an extended enterprise context } \\
\text { - ERPII replaces ERP with SCM and CRM tools to gain medium } \\
\text { inter-integration rather than merely intra-integration } \\
\text { - Shifting from issue-based problem solving into goal seeking strategy } \\
\text { formulation via business-driven 'top-down' approach }\end{array}$ & $\begin{array}{l}\text { By re-classifying the value } \\
\text { members and re-designing } \\
\text { business processes, } \\
\text { Zoomlion's new production } \\
\text { line is based on collaborative } \\
\text { alliances with ERPII systems. }\end{array}$ \\
\hline & $\begin{array}{l}\text { Quadrant } 2 \text { to } \\
\text { Quadrant } 1 \\
\text { From EEs to } \\
\text { VEs by } \\
\text { developing } \\
\text { ERPII into } \\
\text { ERPIII }\end{array}$ & $\begin{array}{l}\text { - Transformation of EE to VE can be adopted incrementally } \\
\text { - Upgrading from ERPII to ERPIII would increase the companies' } \\
\text { flexibility and adaptability for coping with a quick response to the } \\
\text { business environment } \\
\text { - ERPIII, SCM, CRM, applications merged with SOA, SaaS, cloud } \\
\text { computing, etc. can optimize global supply chain integration } \\
\text { - Successful stable ventures trigger the creation of new temporary, agile, } \\
\text { and dynamic ventures } \\
\text { - Requires open minded management with proactive IT/IS strategies } \\
\text { - Focus on temporary market opportunity through short-term } \\
\text { collaboration } \\
\text { - Enterprise strategies shift from company centric into "borderless } \\
\text { enterprises" }\end{array}$ & $\begin{array}{l}\text { In the future Zoomlion may } \\
\text { develop from EE into VE to } \\
\text { address cost-effectiveness, } \\
\text { product uniqueness, business } \\
\text { network optimization, and } \\
\text { short-temporary seamless } \\
\text { issues with industrial third } \\
\text { parties }\end{array}$ \\
\hline
\end{tabular}


The Collaborative Enterprise Governance concept and methodological tools (reference Tables on ERP and enterprise types, Enterprise Matrices and the DERG-ERP) can be used to explain correlations between ERP type and enterprise type, and explain how and why operations and IS strategists could move toward the enterprization of their operations.

\section{SUMMARY}

The objectives of this paper were to (i) summarise recent trends in ERP systems development (ii) summarise recent trends in enterprise management (iii) develop a new contingency framework to explain correlations between ERP system types and enterprise structures and (iv) illustrate them with a longitudinal case study. Thus objective 'i' and 'ii' were met by the literature review and summary Tables (1 and 2); and objective 'iii' was met by combining Binder and Clegg's Collaborative Enterprise Governance (CEG) concept with Galliers' IS Strategy Formulation Model to form the new DERG-ERP. The DERG-ERP partially fills the gap in current literature between ERP systems and the management of multi-organisational enterprises as it provides a practical contingency framework for IS and enterprise managers striving towards sustainable competitive advantage through what the authors coin here first as the "enterprization of operations". Objective 'iv' was met by using the longitudinal case study of Zoomlion where a defunct enterprise evolved into a vertically integrated enterprise through to an extended enterprise, and on towards becoming a virtual enterprise.

The authors do not claim that Zoomlion's, path is the only possible paths that can be taken through the DERG-ERP as a sustainable means to development - as others may be possible. However it was observed that ERP was closely associated with VIE; ERPII with EE; and ERPIII with VE; and limited IS was observed in DEs. Therefore the authors substantiate that these pairings can be correlated theoretically and empirically, and that the DERG-ERP can be a useful strategic tool for operations and IS strategists. The DERG-ERP contingency framework is presently only limited by the fact it is based on the single case study given in this paper. However on-going research is testing it in other service and manufacturing companies in the UK and China. 


\section{REFERENCES}

Achrol, R., \& Kotler, P. (1999). Marketing in the network economy. Journal of Marketing, 63(Special Issue), 146-163.

Akkermans, H., Bogerd, P., Yucesan, E., \& Van Wassenhove, L. (2003). The impact of ERP on supply chain management: exploratory findings from a European Delphi Study. European Journal of Operational Research, 146(2), 284-294.

Al-Mashari, M., Al-Mudimigh, A., \& Zairi, M. (2003). Enterprise resource planning: a taxonomy of critical factors. European Journal of Operational Research, 146, 352-364.

Al-Mudimigh, A., Zairi, M., \& Al-Mashari, M. (2001). ERP software implementation: An integrative framework. European Journal of Information Systems, 10, 216-226.

Alsene, E. (2007). ERP systems and the coordination of the enterprise. Business Process Management Journal, 13(3), 417-432.

Argyres, N.S. (1996). Capabilities technological diversification and divisionalization. Strategic Management Journal, 17, 395-410.

Arya, A., \& Mittendorf, B. (2008). Pricing internal trade to get a leg up on external rivals. Journal of Economics and Management Strategy, 17(3), 709-731.

Bagchi, S., Kanungo, S., \& Dasgupta, S. (2003). Modeling use of enterprise resource planning systems: A path analytic study. European Journal of Information Systems, 12, 142-158.

Bala, H., \& Venkatesh, V. (2007). Assimilation of inter-organizational business process standards, Information Systems Research, 18, 340-362.

Banker, R.D., Chang, H., \& Kao, Y. (2010). Evaluating cross-organizational impacts of information technology-An empirical analysis. European Journal of Information Systems, 19, 153-167.

Bass, T., \& Mabry, R. (2004). Enterprise architecture reference models: A shared vision for Service-Oriented Architectures. IEEE MILCOM, 1-8.

Benlian, A., \& Hess, T. (2011). Comparing the relative importance of evaluation criteria in proprietary and open-source enterprise application software selection - a conjoint study of ERP and Office systems. Information Systems Journal, 21, 503-525. 
Bendoly, E., Soni, A., \& Venkataramanan, M.A. (2004). Value chain resource planning (VCRP): adding value with systems beyond the enterprise. http://www.fc.bus.emory.edu/ elliot_bendoly/VCRP_BH.pdf (accessed 17.1. 2010).

Binder, M., \& Clegg, B.T. (2006). A conceptual framework for enterprise management. International Journal of Production Research, 44(18-19), 3813-3829.

Binder, M., \& Clegg, B.T. (2007a) Enterprise Management: A new Frontier for Organisations. International Journal of Production Economics. 106(2), 409-430

Binder, M., \& Clegg, B. (2007b). Designing and managing collaborative enterprises in the automotive industry. International Journal of Logistics Research and Applications, 10(2), 135-152.

Blackstone, J.H.Jr., \& Cox, J.F. (2005). APICS: The association for operations management. APICS Dictionary, $11^{\text {th }}$ ed., 38 .

Bond, B., Genovese, Y., Miklovic, D., Wood, N., Zrimsek, B., \& Rayner, N. (2000). ERP is dead - long live ERPII. http://www.pentaprise.de/cms_showpdf.php?pdfname=infoc_report (accessed 8.11.2009)

Browne, J., \& Zhang, J. (1999). Extended and virtual enterprises-Similarities and differences. International Journal of Agile Management Systems, 1(1), 30-36.

Buco, M.J., Chang, R.N., Luan, L.Z., Ward, C., Wolf, J.L., \& Yu, P.S. (2004). Utility computing SLA management based upon business objectives. IBM Systems Journal, 43(1), 159-178.

Byrne, J.A., \& Brandt, R. (1993). The virtual corporation. Business Week, February 8, 36-41.

Callaway, E. (2000). ERP - the next generation: ERP is Web enabled for e-business. Computer Technology Research Corporation, Charleston, SC.

Camarinha-Matos, L.M., \& Pantoja-Lima, C. (2001). Cooperation coordination in virtual enterprises. Journal of Intelligent Manufacturing, 12(2), 133-150.

Candido, G., Barata, J., Colombo, A.W., \& Jammes, F. (2009). SOA in reconfigurable supply chain: A research roadmap. Engineering Applications of Artificial Intelligence, 22, 939-949.

Cao, Q., \& Dowlatshahi, S. (2005). The impact of alignment between virtual enterprise and information technology on business performance in an agile manufacturing environment. Journal of Operations Management, 23, 531-550.

Chen, I.J. (2001). Planning for ERP systems: Analysis and future trend. Business Process Management Journal, 7(5), 374-386.

Childe, S.J. (1998). The extended enterprise - a concept of co-operation. Production Planning \& 
Control, 9(4), 320-327.

Cho, H., Jung, M., \& Kim, M. (1996). Enabling technologies of agile manufacturing and its related activities in Korea. Computers and Industrial Engineering, 30(3), 323-334.

Chorafas, D.N. (2001). Integrating ERP, CRM, supply chain management, and smart materials. CRC Press LLC, Auerbach Publications, 13.

Clegg, B. (2003). The extended enterprise: a matrix framework for effective strategic operations management. In Proceedings of the $20^{\text {th }}$ International Manufacturing Conference IMC 20 (ed. Matthew Cotterell). Cork, Ireland.

Clegg, B., Chandler, S., Binder, M., \& Edwards, J. (2012). Governing inter-organizational R\&D supplier collaborations: a study at Jaguar Land Rover. Production Planning \& Control, 1-19, iFirst.

Crandall, R. (1968). Vertical integration and the market for repair parts in the United States Automobile Industry. The Journal of Industrial Economics, 16(3), 212-234.

Cummins, F. A. (2009). Building the agile enterprise with SOA, BPM and MBM. Burlington, USA: Morgan Kaufmann Publishers, Elsevier Inc.

Daniel, E.M., \& White, A. (2005). The future of inter-organizational system linkages: Findings of an international delphi study. European Journal of Information Systems, 14, 188-203.

Daniels, S. (1998). The virtual corporation. Work Study, 47(1), 20-22.

Davenport, T.H. (1998). Putting the enterprise into the enterprise system. Harvard Business Review, 121-131.

Davenport, T.H., \& Brooks, J.D. (2004). Enterprise systems and the supply chain. Journal of Enterprise Information Management, 17(1), 8-19.

Davis, E.W., \& Spekman, R.E. (2003; 2004). Extended enterprise: Gaining Competitive Advantage through Collaborative Supply Chains. New York, USA: Financial Times Prentice-Hall, 20.

De Maria, F., Briano, C., Brandolini, M., Briano, E., \& Revetria, R. (2011). Market-leader ERPs and cloud computing: a proposed architecture for an efficient and effective synergy. In Proc. of the $10^{\text {th }}$ WSEAS Conference on Applied Computer and Applied Computational Science. Wisconsin, USA, 13-19.

De Toni, A. and Tonchia, S. (2003), Strategic planning and firms' competencies: traditional approaches and new perspectives, International Journal of Operations \& Production Management, (23)9, 947-976. 
Doz, Y.L., \& Hamel, G. (1998). Alliance advantage. The Art of Creating Value Through Partnering. Boston, Harvard Business School Press.

Dyer, J.H. (1996). Specialized supplier networks as a source of competitive advantage: evidence from the auto industry. Strategic Management Journal, 17, 271-291.

Eckartz, S., Daneva, M., Wieringa, R., \& Hillegersberg, J.V. (2009). Cross-organizational ERP management: How to create a successful business case? In SAC'09 Proceedings of the 2009 ACM Symposium on Applied Computing. Honolulu, Hawaii, USA.

Ericson, (2001). What the heck is ERPII? http://www.line56.com/articles/default.asp?ArticleID=2851 (accessed 27.5.2012)

Esteves, J. (2009). A benefits realisation road-map framework for ERP usage in small and medium-sized enterprises. Journal of Enterprise Information Management, 22(1/2), 25-35.

European Commission (2003). Commission recommendation of 6 May 2003 Concerning the Definition of Micro, Small and Medium Sized Enterprises. Official Journal of the European Union, L124, 1422, $36-41$.

Gallivan, M.J., \& Depledge, G. (2003). Trust, control and the role of inter-organizational systems in electronic partnerships. Information Systems Journal, 13, 159-190.

Galliers, R.D. (1994). Information systems, operational research and business reengineering. International Transactions in Operational Research, 1(2), 159-167.

Goranson, H.T. (1999). The agile virtual enterprise: Cases, metrics, tools. Quorum Books, USA: Greenwood Publishing Group, Inc., 65.

Harrigan, K.R. (1984). Formulating vertical integration strategies. Academy of Management Review, 9, 638-652.

Harrigan, K.R. (1985). Vertical integration and corporate strategy. Academy of Management Journal, 28(2), 397-425.

Hauser, K., Sigurdsson, H.S., \& Chudoba, K.M. (2010). EDSOA: an event-driven service-oriented architecture model for enterprise applications. International Journal of Management \& Information Systems, 14(3), 37-47.

He, X. (2004). The ERP challenge in China: a resource-based perspective. Information Systems Journal, 14, 153-167. 
Henningsson, S., \& Carlsson, S. (2011). The DySIIM model for managing IS integration in mergers and acquisitions. Information Systems Journal, 21(5), 441-476.

Hicks, D.A., \& Stecke, K.E. (1995). The ERP maze: enterprise resource planning and other production and inventory control software. IIE Solutions, 27, 12-16.

Hofmann, P. (2008). ERP is dead, long live ERP. Internet Computing, IEEE, 12(4), 84-88.

Hye, P.K., \& Joel, F. (1999). Virtual enterprise - information system and network solution. Computers \& Industrial Engineering, 37, 441-444.

Hyvonen, T., Jarvinen, J., \& Pellinen, J. (2008). A virtual integration - the management control system in a multinational enterprise. Management Accounting Research, 19, 45-61.

Jagdev, H.S., \& Browne, J. (1998). The extended enterprise - a context for manufacturing. Production Planning \& Control, 9(3), 216-229.

Jaiswal, M.P., \& Kaushik, A. (2005). Realising enhanced value due to business network redesign through extended ERP systems: case study of HLLNet. Business Process Management Journal, 11(2), 171-184.

Joskow, P. (2002). Electricity sector restructuring and competition: a transaction cost perspective. In E. Brousseau and J.-M. Glachant (eds), The Economics of Contracts: Theories and Applications, Cambridge University Press.

Joskow, P.L. (2003). Vertical integration. Handbook of New Institutional Economics, Kluwer, December 2, 25.

Karlsson, C. (2003). The development of industrial networks: challenges to operations management in an extraprise, International Journal of Operations \& Production Management, (23)1, 44-61.

Kasper-Fuehrer, E.C., \& Ashkanasy, N.M. (2001). Communicating trustworthiness and building trust in interorganizational virtual organizations. Journal of Management, 27, 235-254.

Khoo, B., Harris, P., \& Hartman, S. (2010). Information security governance of enterprise information systems: an approach to legislative compliant. International Journal of Management \& Information Systems, 14(3), 49-55.

King, N. (2004). Using templates in the thematic analysis of texts. In: Cassell, C. \& Symon, G. (eds.) Essential guide to qualitative methods in organizational research. London: Sage Publications. 
Li, C. (1999). ERP packages: what's next? [Electronic version] Information Systems Management, $16(3), 31-36$.

Li, F., \& Williams, H. (1999). Interfirm collaboration through interfirm networks. Information Systems Journal, 9, 103-115.

Lipnack, J., \& Stamps, J. (1997). Virtual teams. In: Reaching Across Space, Time, and Organizations with Technology. John Wiley \& Sons, New York.

Lyman, K.B., Caswell, N., \& Biem, A. (2009) Business value network concepts for the extended enterprise. In Proc. of the Network Experience (PHM Vervest et al., Eds), Springer-Verlag Berlin Heidelberg 2009.

Lynch, R. (2003). Corporate strategy. Third ed., Harlow: Prentice Hall Financial Times.

MacBeth, D.K. (2002). Emergent strategy in managing cooperative supply chain change, International Journal of Operations \& Production Management, (22)7, 728- 740.

Madu, C.N., \& Kuei, C. (2004). ERP and supply chain management. Chi Publishers: Fairfield, CT.

Markus, M.L., \& Tanis, C. (2000). The enterprise system experience - from adoption to success, in Zmud, R.W. (Ed.), Framing the domains of IT management: projecting the future through the past, Pinnaflex Educational Resources, Inc., Cincinnatti, OH, 173-207.

Martinez, M.T., Fouletier, P., Park, K.H., \& Faurel, J. (2001). Virtual enterprise: Organization, evolution and control. International Journal of Production Economics, 74, 225-238.

Maurizio, A., Girolami, L., \& Jones, P. (2007). EAI and SOA: Factors and methods influencing the integration of multiple ERP systems (in an SAP environment) to comply with the Sarbanes-Oxley Act. Journal of Enterprise Information Management, 20(1), 14-31.

McAfee, A. (2002). The impact of enterprise information technology adoption on operational performance: an empirical investigation. Production and Operations Management, 11(1), 33-53.

Michel, R. (2000). The road to extended ERP. http://www.manufacturingsystems.com/extendedenterprise (accessed 8.5.2009).

Moller, C. (2005). ERPII: A conceptual framework for next-generation enterprise systems? Journal of Enterprise Information Management, 18(4). 483-497.

Monk, E.F., \& Wagner, B.J. (2009). Concepts in enterprise resource planning. Third Edition, Course Technology, Cengage Learning, USA. 
Monteverde, K., \& Teece, D.J. (1982). Supplier switching costs and vertical integration in the automobile industry. The Bell Journal of Economics, 13(1), 206-213.

Muscatello, J.R., Small, M.H., \& Chen, I.J. (2003). Implementing enterprise resource planning (ERP) systems in small and midsize manufacturing firms. International Journal of Operations \& Production Management, 23(8), 850-871.

Nah, F., Faja, S., \& Cata, T. (2001). Characteristics of ERP software maintenance: a multiple cast study. Journal of Software Maintenance, 13(6), 1-16.

Ó hUallacháin, B., \& Wasserman, D. (1999). Vertical integration in a lean supply chain: Brazilian automobile component parts. Economic Geography, 75, 21-42.

Olsen, K.A., \& Sætre, P. (2007). IT for niche companies: is an ERP system the solution? Information Systems Journal, 17, 37-58.

O’Neil, H., \& Sackett, P. (1994). The extended manufacturing enterprise paradigm. Management Decision, 32(8), 42-49.

Owen, L., Goldwasser, C., Choate, K., \& Blitz, A. (2008). Collaborative innovation throughout the extended enterprise. Strategy and Leadership, 36(1), 39-45.

Pal, N., \& Pantaleo, D.C. (2005). The agile enterprise: Reinventing your organization for success in an on-demand world. New York, USA: Springer Science, Business Media, Inc.

Palaniswamy, R., \& Frank, T. (2000). Enhancing manufacturing performance with ERP systems. Information Systems Management, 17(3), 1-13.

Park, K., \& Kusiak, A. (2005). Enterprise resource planning (ERP) operations support system for maintaining process integration. International Journal of Production Research, 43(19), 3959-3982.

Ponis, S.T., \& Spanos, A.C. (2009). ERPII systems to support dynamic, reconfigurable and agile virtual enterprises. International Journal of Applied Systemic Studies, 2(3). 265-283.

Porter, M., \& Millar, V.E. (1985). How information gives you competitive advantage. Harvard Business Review, 63(4), 149-160.

Rappa, M.A. (2004). The utility business model and the future of computing services. IBM Systems Journal, 43(1), 32-42.

Rayport, J.F., \& Sviokla, J.J. (1995). Exploiting the virtual value chain. The McKinsey Quarterly, 1, 21-36.

Richardson, J. (1996). Vertical integration and rapid response in fashion apparel. Organization Science, $7(4), 400-412$. 
Rodon, J., Sese, F., \& Christiaanse, E. (2011). Exploring users' appropriation and post-implementation managerial intervention in the context of industry IOIS. Information Systems Journal, 21, 223-248.

Rothaermel, F.T., Hitt, M.A., \& Jobe, L.A. (2006). Balancing vertical integration and strategic outsourcing: Effects on product portfolio, product success, and firm performance. Strategic Management Journal, 27, 1033-1056.

Scott, J.E., \& Vessey, I. (2000). Implementing enterprise resource planning systems: the role of learning from failure. Information Systems Frontiers, 2(2), 213-232.

Shang, S., \& Seddon, P.B. (2000). A comprehensive framework for classifying the benefits of ERP systems. Americas Conference on Information Systems (AMCIS) 2000 Proceedings, paper 39, 1005-1014. http://aisel.aisnet.org/amcis2000/39.

Sharif, A.M., Irani, Z. \& Love, P.E.D. (2005). Integrating ERP with EAI: a model for post-hoc evaluation. European Journal of Information Systems, 14(2), 162-174.

Sharp, J.M., Irani, Z., \& Desai, S. (1999). Working towards agile manufacturing in the UK industry. International Journal of Production Economics, 62, 155-169.

Songini, M.L. (2002). J.D. Edwards pushes CRM, ERP integration, Computerworld, 36(25), 4.

Stevens, C.P. (2003). Enterprise resource planning: A trio of resources. Information Systems Management, 20(3), 61-71.

Sutton, S.G. (2006). Extended-enterprise systems' impact on enterprise risk management. Journal of Enterprise Information Management, 19(1), 97-114.

Tapscott, D., Ticoll, D., \& Lowy, A. (2000). Digital Capital. Harvard Business School Press, Boston, MA.

Tencati, A., \& Zsolnai, L. (2009). The collaborative enterprise. Journal of Business Ethics, 85(3), 367-376.

Themistocleous, M., Irani, Z., \& O’Keefe, R. (2001). ERP and application integration: Exploratory survey. Business Process Management Journal, 7(3), 195-204.

Thun, J.H. (2010). Angles of Integration: An empirical analysis of the alignment of internet-based information technology and global supply chain integration. Journal of Supply Chain Management, $46(2), 30-44$. 
Torbacki, W. (2008). SaaS - direction of technology development in ERP/MRP systems. Archives of Materials Science and Engineering, 31(1), 57-60.

Triantafillakis, A., Kanellis, P., \& Martakos, D. (2004). Data warehousing interoperability for the extended enterprise. Journal of Database Management, 15(3), 73-82.

Vallespir, B., \& Kleinhans, S. (2001). Positioning a company in enterprise collaborations: Vertical integration and make-or-buy decisions. Production Planning and Control, 12, 478-487.

Vathanophas, V. (2007). Business process approach towards an inter-organizational enterprise system. Business Process Management Journal, 13(3), 433-450.

Vazquez-Bustelo, D. and Avella, L. (2006). Agile Manufacturing: Industrial Case Studies in Spain, Technovation, 26, 1147-1161.

Wallace, T.F., \& Kremzar, M.H. (2001). ERP: making it happen: the implementer's guide to success with enterprise resource planning. John Wiley \& Sons Inc., New York.

Weston, F.C. “Ted," Jr. (2002). A vision for the future of extended enterprise systems. Presentation, J.D. Edwards FOCUS users Conference, Denver, Colorado (12 June).

Weston, F.C. "Ted," Jr. (2003). ERPII: the extended enterprise system. Business Horizons, November-December, 49-55.

Wilkes, L., \& Veryard, R. (2004). Service-Oriented Architecture: Considerations for agile systems. Microsoft Architect Journal, April. URL http://www.msdn2.microsoft.com (accessed 16.5.2010).

Wood, B. (2010). ERP vs. ERPII vs. ERPIII future enterprise applications. http://www.r3now.com/erp-vs-erp-ii-vs-erp-iii-future-enterprise-applications (accessed 3.10.2010).

Xu, W., Wei, Y., \& Fan, Y. (2002). Virtual enterprise and its intelligence management. Computers \& Industrial Engineering, 42, 199-205.

Zhang, C., \& Dhaliwal, J. (2008). An investigation of resource-based and institutional theoretic factors in technology adoption for operations and supply chain management. International Journal of Production Economics, 120(1) 252-269.

Zrimsek, B. (2003). ERPII vision. US symposium/ITxpo. 23-27 March 2003. Gartner Research (25C, SPG5, 3/03), San Diego. 